\title{
ANTIBODY RESPONSE AFTER SARS-CoV-2 mRNA VACCINE IN NAÏVE AND PREVIOUSLY INFECTED HEALTHCARE WORKERS
}

\section{ODPOWIEDŹ NA PRZECIWCIAŁA PO SZCZEPIONCE mRNA SARS-CoV-2 U UPRZEDNIO NIEZAINFEKOWANYCH ORAZ ZAINFEKOWANYCH PRACOWNIKÓW MEDYCZNYCH}

\author{
Adina Huțanu ${ }^{1(\mathrm{~A}, \mathrm{~B}, \mathrm{C}, \mathrm{D}, \mathrm{E}, \mathrm{F}, \mathrm{G})}$, Minodora Dobreanu ${ }^{1,2(\mathrm{~A}, \mathrm{D}, \mathrm{E})}$ \\ ${ }^{1}$ Faculty of Medicine, “George Emil Palade” University of Medicine, Pharmacy, Science and Technology, \\ Târgu Mureș, Romania \\ ${ }^{2}$ Department of Immunology, Center for Advanced Medical and Pharmaceutical Research, "George Emil Palade" \\ University of Medicine, Pharmacy, Science and Technology, Târgu Mureș, Romania
}

Authors' contribution Wkład autorów: A. Study design/planning zaplanowanie badań B. Data collection/entry zebranie danych C. Data analysis/statistics dane - analiza i statystyki D. Data interpretation interpretacja danych E. Preparation of manuscript przygotowanie artykułu F. Literature analysis/search wyszukiwanie i analiza literatury G. Funds collection zebranie funduszy

Tables: 2

Figures: 4

References: 28

Submitted: 2021 Sep 20

Accepted: 2021 Nov 30

\section{Summary}

Background. Evaluating and monitoring plasma levels of anti-SARS-CoV-2 antibodies in healthcare workers, together with the vaccination of this at-risk population is important for maintaining the viability of the healthcare system, especially during the emergence of new viral variants. The aim of this study is to investigate plasma levels of anti-SARS-CoV-2 antibodies in healthcare providers following full vaccination, in both naïve and previously infected individuals.

Material and methods. Complete data was available for 89 healthcare workers from the larger group of 102 initial participants. Plasma was collected at least one month, and no later than two months after the full dose of an mRNA vaccine, and analyzed by determining the total antibody concentration against the spike protein using an ECLIA kit.

Results. The degree of humoral-specific immune response was at least 5 -fold higher in previously infected healthcare workers compared to naïve persons that received the vaccine only. The highest titer was found in office-based staff, relative to those found in doctors and nurses. However, this difference lacks statistical significance. Among previously infected participants, nurses had significantly higher antibody titers, when compared to doctors.

Conclusions. The study revealed a sustained immune response after mRNA vaccine among healthcare workers, with enhanced response in previously infected subjects, highlighting a boosting effect of the vaccine.

Keywords: COVID-19 antibody testing, mRNA vaccine, immune response, COVID-19, healthcare workers

\section{Streszczenie}

Wprowadzenie. Ocena i monitorowanie stężenia przeciwciał anty-SARS-CoV-2 w osoczu pracowników służby zdrowia oraz szczepienia tej szczególnej grupy ryzyka są ważne do utrzymania sprawności systemu opieki zdrowotnej, zwłaszcza w przy padku pojawienia się nowych wariantów wirusa. Celem pracy jest zbadanie poziomu przeciwciał anty-SARS-CoV-2 w osoczu pracowników służby zdrowia po pełnym szczepieniu, zarówno u osób wcześniej niezainfekowanych, jak i zainfekowanych.

Materiał i metody. Kompletne dane były dostępne dla 89 pracowników służby zdrowia pochodzących z większej, wstępnej grupy 102 uczestników. Osocze pobierano co najmniej 1 miesiąc, a nie później niż 2 miesiące po podaniu pełnej dawki szczepionki mRNA i analizowano poprzez określenie całkowitego stężenia przeciwciał skierowanych przeciwko białku S przy użyciu zestawu ECLIA.

Wyniki. Stopień humoralnej odpowiedzi swoistej był co najmniej 5-krotnie wyższy u uprzednio zakażonych pracowników służby zdrowia w porównaniu z osobami wcześniej niezainfekowanymi, które otrzymały tylko szczepionkę. Wyższe miano stwierdzono wśród osób pracujących w biurze niż u lekarzy i pielęgniarek, jednak różnica ta nie jest istotna statystycznie. Wśród wcześniej zakażonych uczestników pielęgniarki miały znacząco wyższe miana przeciwciał w porównaniu z lekarzami.

Wnioski. Badanie wykazało trwałą odpowiedź immunologiczną po podaniu szczepionki mRNA wśród pracowników służby zdrowia, a także zwiększoną odpowiedź u osób wcześniej zakażonych, co podkreśla wzmacniający efekt szczepionki.

Słowa kluczowe: testowanie przeciwciał COVID-19, szczepionka mRNA, odpowiedź immunologiczna, COVID-19, pracownicy służby zdrowia

Huțanu A, Dobreanu M. Antibody response after SARS-CoV-2 mRNA vaccine in naïve and previously infected healthcare workers. Health Prob Civil. 2022; 16(1): 48-56. https://doi.org/10.5114/hpc.2021.111783

Address for correspondence / Adres korespondencyjny: Adina Huțanu, Faculty of Medicine, "George Emil Palade” University of Medicine, Pharmacy, Science and Technology, Gheorghe Marinescu 38, 540142 Târgu Mureș, Romania, e-mail: adina_hutanu03@yahoo.com, phone: +40 744 300508 ORCID: Adina Huțanu https://orcid.org/0000-0001-9798-1594, Minodora Dobreanu https://orcid.org/0000-0003-3214-3631

Copyright: (C) John Paul II University of Applied Sciences in Biala Podlaska, Adina Huțanu, Minodora Dobreanu. This is an Open Access journal, all articles are distributed under the terms of the Creative Commons Attribution-NonCommercial-ShareAlike 4.0 International (CC BY-NC-SA 4.0) License (http://creativecommons.org/ licenses/by-nc-sa/4.0/), allowing third parties to copy and redistribute the material in any medium or format and to remix, transform, and build upon the material, provided the original work is properly cited and states its license. 


\section{Introduction}

The vaccination of healthcare workers (HWs) against COVID-19 was a necessary condition for sustained and safe activity of medical staff. Although the doses were limited in the first stages of vaccination, medical staff were prioritized due to the at-risk nature of their work. In Romania, beginning December 27, 2020, the vaccination process has been included for front-line medical personnel. While many doctors, nurses, or other HWs became infected with SARS-CoV-2 by the time the vaccination campaign started, most accepted vaccination as an additional preventive measure. Persons previously infected are considered to have protective immunity for several months [1,2]. Since the protective titer or neutralizing capacity of the antibodies is not yet known, vaccination may be considered as a "reboot" for memory lymphocytes [3]. In this regard, throughout this study we analyzed comparative antibody responses after full dose vaccination in HWs with and without previous SARS-CoV-2 infection.

There are many types of serological tests [4], although most that are used in daily practice assess the binding capacity of the antibody, not the neutralizing potency. Differences arise from either the target epitope of the assay (e.g. S1, RBD, N-terminal domain, or nucleocapsid), the immunoglobulin isotypes (IgG, IgM, or IgA), or assay format. Interestingly, the neutralization assays are often used as a reference method to evaluate the performance of antibodies to the detriment of binding assays [5]. The performance of the binding assays is highly variable as the methods can be very different, from point-of-care tests such as Lateral Flow Assay (LFA), to EnzymeLinked Immunosorbent Assay (ELISA) and other immunological tests [6] suitable for automation. Automated immunological assays include electrochemiluminescence immunoassay (ECLIA), chemiluminescence assay (CLIA) or chemiluminescent microparticle immunoassay (CMIA). However, none of these use the international standard that was introduced at the end of 2020 [7]. Some assay measure individual antibody isotype, while others quantify the overall binding capacity in relation to the neutralizing potency [8]. These antibodies appear after 10-15 days post symptom onset and by day 19, 100\% of SARS-CoV-2 positive patients were found to have IgG-specific antibodies [9]. In the post-vaccination setting, the antibodies titers rise after approximately 14 days post-vaccine [10].

The vaccination of HWs was an important step in limiting viral evolution, since the vaccination is effective in both reducing the transmissibility [11] and reducing the infection rate [12]. Thus, vaccination has a great impact on reducing the burden of the disease by interfering with the chain of transmission [13] and by creating a safe environment for patients that utilize the health care system. Transmission among HWs occurs mainly due to exposure to infected patients, especially if the hospital was a COVID-19 facility. Previous literature has revealed that antibody titers are higher after some types of vaccines compared to natural infection [14]. Various mechanisms could be responsible for this, including different antigen presentation or location (upper respiratory tract vs general virus exposure after vaccine inoculation), which may lead to higher neutralizing antibody titer or better recognition of the SARS-CoV-2 variants for the vaccine-induced immune response. Conversely, the immune response is more complex following infection, and potentially more diluted for the main antigenic target, as it is directed against multiple viral epitopes. Finally, in some cases there is a more specific and narrower targeted immune-specific response following vaccine administration.

Because of the paramount importance of immunization among HWs, our study aimed to evaluate antibody titers (in terms of binding capacity) among medical staff and, in a few cases, their relatives or householders that had received the full-dose vaccine either with or without previous disease.

\section{Material and methods}

The study was approved by the Ethical Committee of the Emergency Clinical County Hospital Târgu Mureș, Romania, (no. Ad.30499/8.12.2020) and informed consent was obtained from all participants. There were 102 participants recruited, who were medical staff with various specializations, or office-based personnel from two hospitals, namely the Emergency Clinical County Hospital and Infectious Disease Hospital in Târgu Mureș, between March and May 2021. The inclusion criteria were: greater than 18 years of age, full vaccination, interval between the first and second dose of no more than two months (recommendation for the 2nd dose was three weeks after the first), naïve or previously infected with SARS-CoV-2. Data regarding any previous SARS-CoV-2 infection with details about the symptoms, duration of the disease, therapy, comorbidities, and vaccination status were collected on a clinical data form. The participants with previous SARS-CoV-2 infection were defined as subjects with confirmed infection based on a positive real-time PCR test, in accordance with legal regulations.

All participants received a self-reporting questionnaire covering the main aspects addressed in this study, namely demographic data, comorbidities, disease history, treatment, and any vaccination side effects. Complete 
data was obtained for 89 participants, while the remainder were excluded from the study. All participants were vaccinated with two doses of BNT162b2 mRNA COVID-19 vaccine (Pfizer-BioNTech). Blood collection was between one and two months post-second vaccination dose. Venous blood samples were collected using a vacuum system in $\mathrm{K}_{3}$ EDTA tubes, were centrifuged at $2500 \mathrm{~g}$, the plasma was aliquoted, and stored at $-20^{\circ} \mathrm{C}$ until analyzed. The antibody titer (as binding capacity) was evaluated using the automated Cobas e411 analyzer (Roche Diagnostics Germany $\mathrm{GmbH}$ ), using the latest generation electrochemiluminescence (ECLIA) assay to detect anti-SARS-CoV-2 S antibodies. The test consists of a double-antigen sandwich principle, using two recombinant SARS-CoV-2 Spike (S) Receptor Binding Domain (RBD) proteins, one biotinylated and the other one labeled with ruthenium. After binding to anti-SARS-CoV-2, mostly IgG and to a lesser extent anti-SARSCoV-2 IgA and IgM [15], the magnetic beads coated with the generated immune complexes were aspirated into a measuring cell, where they were captured on the inner electrode. By applying a voltage on the electrode, a chemiluminescent emission is generated, proportional with the antibody concentration in the sample. The characteristics of performance for the test according to the manufacturer are as follows: sensitivity $98.9 \%$, clinical specificity 99.98\%, analytical specificity 100\%, and intra- and inter-assay coefficients of variation (CV) were $1.3 \%$ and $2.0 \%$ respectively. The high analytical specificity declared by the manufacturer was reported after analysis of more than 1400 pre-pandemic samples from patients with serological reactivity for other coronaviruses or with flu-like symptoms. All samples containing potential cross-reacting analytes including Influenza A and B as well as influenza vaccines showed no cross-reactivity with anti-S-RBD antibodies [15].

The analytical range was between $0.40-250 \mathrm{U} / \mathrm{mL}$, the cut-off value for positive results was set by the manufacturer at $0.80 \mathrm{U} / \mathrm{mL}$ and the concordance rate between the estimated binding capacity and the neutralizing capacity of the sera when evaluated by pseudo-virus-neutralizing test (pVNT) was 92.3\% [15]. Additionally, a medical decision cut-off of $15 \mathrm{U} / \mathrm{mL}$ was set for the optimal neutralizing capacity with the $100 \%$ probability of achieving the neutralizing effect against the SARS-CoV-2 virus. Interestingly, the Food and Drug Administration (FDA) has defined the value of equal or greater than $132 \mathrm{U} / \mathrm{mL}$ as the minimum antibody titer to classify convalescent plasma as having high neutralizing capacity [15]. All samples that exceeded the maximal signal generated by the highest calibrator were diluted according to the protocol (maximal dilution factor was 100), and the results were multiplied by the dilution factor accordingly. However, the values that exceeded $25000 \mathrm{U} / \mathrm{mL}$ (highest calibrator value multiplied by the dilution factor of 100) were not further diluted and were reported as $25000 \mathrm{U} / \mathrm{mL}$. For statistical analysis, the group was separated into 1) naïve (without previous SARS-CoV-2 infection) with full-dose vaccination and 2) previously infected and fully vaccinated.

The statistical analysis was performed using MedCalc Statistical Software v14.8.1 (MedCalc Software bvba, Ostend, Belgium). Continuous variables (mean \pm SD) were analyzed using Student's t-test, while nonparametric variables were analyzed using a Mann-Whitney test. Multiple groups were examined using an ANOVA with Kruskal-Wallis and the results were expressed as the median and interquartile range (IQR), or median (min. max.). For analysis of the qualitative variables, we used contingency tables and a chi-square or Fisher exact test. A $p$-value of $<0.05$ was considered statistically significant.

\section{Results}

The occupations and work-places of the participants are detailed below (Figures 1 and 2).

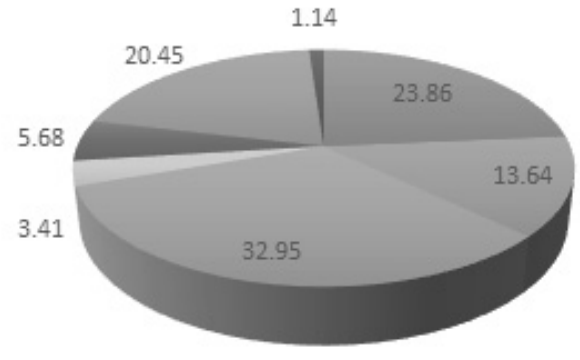

doctors

aresident doctors $\mathbf{m}$ nurses

caretaker
3.41

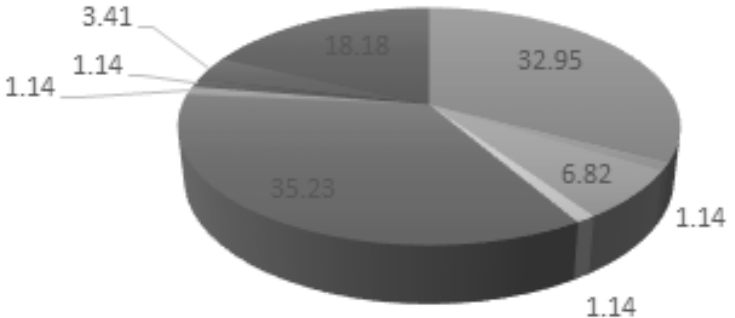

- laboratory

In forensic medicine - nefrology a cardiology

neurology

- research center n infectious diseases clinic

11 neurosurgery

- office based staff

Figure 1. The occupational profile for the study participants with values expressed as percentage (\%)

Figure 2. The working place for the participants included in the study with values expressed as a percentage (\%) 
There were 89 participants included (79.8\% women and $20.2 \%$ men) in this study, with a median age of 44 years (min. 22 - max. 66 years). The participants were separated into two groups, namely those with (48.3\%) and without (51.6\%) SARS-CoV-2 infection prior to vaccination with a full dose of the Pfizer-BioNTech vaccine. Both groups displayed an uneven gender distribution, with the vaccine-only (VO) group (n=46) consisting of $39(84.7 \%)$ females and $7(15.2 \%)$ males, while the infected + vaccination (IV) group ( $\mathrm{n}=43$ ) comprised of 32 (74.4\%) females and $11(25.6 \%)$ males.

The median time in weeks between infection and the first dose of vaccine administration was 8 weeks (min. 4 - max. 13 weeks), while the median time between the last vaccine dose and sample collection was 5 weeks (min. 4 - max. 7 weeks). In one case, disease onset was after the first dose of the vaccine; thus the second vaccine dose was postponed according to the recommendations [16] and after recovery from the inflammatory syndrome. Antibody levels in the two vaccinated groups (naïve vs infected) in relation to age, sex, profession, working location are detailed in Table 1 . As age and sex may impact the immune response, we analyzed the antibody titers for the overall group and did not find a significant difference between participants aged 20-40 years or those between 41-66 years. However, antibody levels for both VO and IV groups were higher in younger subjects (20-40 years), although this did not reach statistical significance.

Participants' antibody titers were evaluated in relation to their work-place by classifying them into three groups, namely office-based, paraclinical (laboratory + research center), and clinical. This was done to avoid small group numbers in the various clinical specialties in which the participants worked (e.g. cardiology, forensic medicine, neurosurgery, etc.).

Table 1. The anti-SARS-CoV-2 S antibody titer (U/mL) in binding capacity in different groups, classified according to age, sex, occupation and work place

\begin{tabular}{|c|c|c|c|c|}
\hline & Total & Vaccine only group (V0) & $\begin{array}{c}\text { Infected + vaccine group } \\
\text { (IV) }\end{array}$ & $p$ \\
\hline \multirow{2}{*}{ All participants $(\mathrm{N})$} & \multirow{2}{*}{89} & 46 & 43 & \\
\hline & & $1228.0(550.0-2055.0)$ & $7520.0(4092.25-13142.25)$ & $<0.0001$ \\
\hline Women & $2367.0(1025.0-7444.25)$ & $1297.0(512.5-2210.75)$ & $7797.0(4707-12570.5)$ & $<0.0001^{2}$ \\
\hline Men & $\begin{array}{c}2957.5(1277.0-4986.0) \\
P^{1}=0.557 \\
\end{array}$ & $\begin{array}{c}637.0(593.25-1424.0) \\
P^{1}=0.668\end{array}$ & $\begin{array}{c}4864.0(3367.75-13067.5) \\
\qquad P^{1}=0.509\end{array}$ & $0.0005^{2}$ \\
\hline $\begin{array}{c}\text { Age (years), median } \\
\text { (IQR) }\end{array}$ & $44.0(37.7-50.2)$ & $42(39.0-50.0)$ & $45.0(36.2-51.7)$ & 0.593 \\
\hline $\begin{array}{l}\text { Antibody titers } \\
\text { 20-40 years } \\
\text { 41-66 years }\end{array}$ & $\begin{array}{c}2408.50(1228.0-6641.75) \\
2435.0(805.75-7568.5) \\
P^{1}=0.596\end{array}$ & $\begin{array}{c}1375.0(627.0-2260.0) \\
1019.0(435.6-1885.0) \\
\text { NS }\end{array}$ & $\begin{array}{c}8010.0(5400.0-14070.0) \\
7520.0(3802.0-11998.75) \\
\mathrm{NS}\end{array}$ & $\begin{array}{l}<0.0001^{2} \\
<0.0001^{2}\end{array}$ \\
\hline \multicolumn{5}{|c|}{ Occupation } \\
\hline Doctors $^{\#}$ & $2367.0(1073.0-4440.0)$ & $1277.0(693.25-2210.0)$ & $4578.0(2664.0-10264.0)$ & $0.0018^{2}$ \\
\hline Nurses $^{\%}$ & $2382.50(594.0-6838.0)$ & $896.0(430.75-1881.25)$ & $7714.0(5541.5-12915.0)$ & $<0.0001^{2}$ \\
\hline \multirow[t]{2}{*}{ Office-based staff } & $5349.50(1331.5-14723.5)$ & $1331.5(582.0-1548.0)$ & $10743.5(4986.0-25000.0)$ & 0.009 \\
\hline & $\begin{array}{l}p^{1}=0.205 ; P^{\$}=0.877 ; \\
P^{@}=0.077 ; P^{\&}=0.139\end{array}$ & & & \\
\hline \multicolumn{5}{|c|}{ Working place } \\
\hline Laboratory & $1715.0(671.50-2787.50)$ & $1358.50(550.0-2367.0)$ & $10518.0(5557.7-18841.5)$ & $0.0006^{2}$ \\
\hline Clinical & $3084.00(1142.0-7714.0)$ & $766.5(500.0-1473.0)$ & $6061.5(3084.0-10211.5)$ & $<0.0001^{2}$ \\
\hline \multirow[t]{2}{*}{ Office-based } & $5349.50(1331.5-14723.5)$ & $1331.50(582.0-1548.0)$ & $10743.5(4986.0-25000.0)$ & $0.009^{2}$ \\
\hline & $P^{1}=0.023$ & & & \\
\hline
\end{tabular}

Notes: Values are expressed as median and interquartile range (IQR). " = including residents, biologists, and medical students; ${ }^{\%}=$ nurses and other caretakers; ${ }^{1}=p$ for overall group comparison; ${ }^{\$}=p$ for statistical comparison between doctors and nurses ${ }^{\circledR}=p$ for statistical comparison between doctors and office-based staff; ${ }^{\circledR}=p$ for statistical comparison between nurses and office-based staff; ${ }^{2}=p$ for statistical comparison between VO and IV groups; NS=not statistically significant. 
We then examined antibody titers expressed for the different categories of medical and non-medical participants, finding that titers were significantly higher for office-based staff than for medical or nursing staff (Figures 3 and 4).

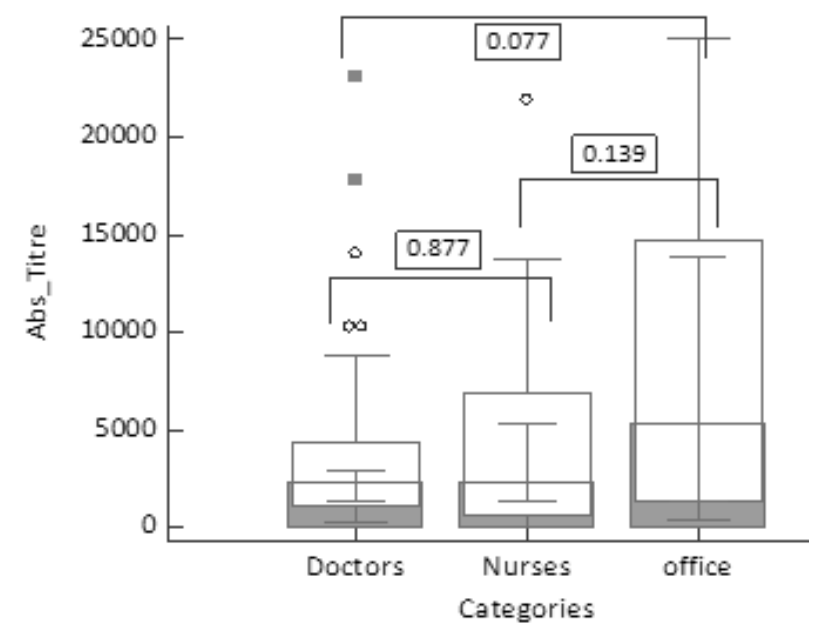

Figure 3. Antibodies titers $(\mathrm{U} / \mathrm{mL})$ in different categories of hospital personnel (doctors, nurses, and office-based staff) after the second vaccine dose

Notes: Differences between overall groups regardless of COVID-19 personal history were analyzed using the Kruskal-Wallis test for nonparametric data. The white box represents IQR, the grey box represents the lowest quartile, the horizontal line inside the box represents the median and the whiskers inside the box represent 95\% CI for the median. Whiskers represent the extend from the IQR to the maximum values that are not considered as outliers, square dots represent outliers.

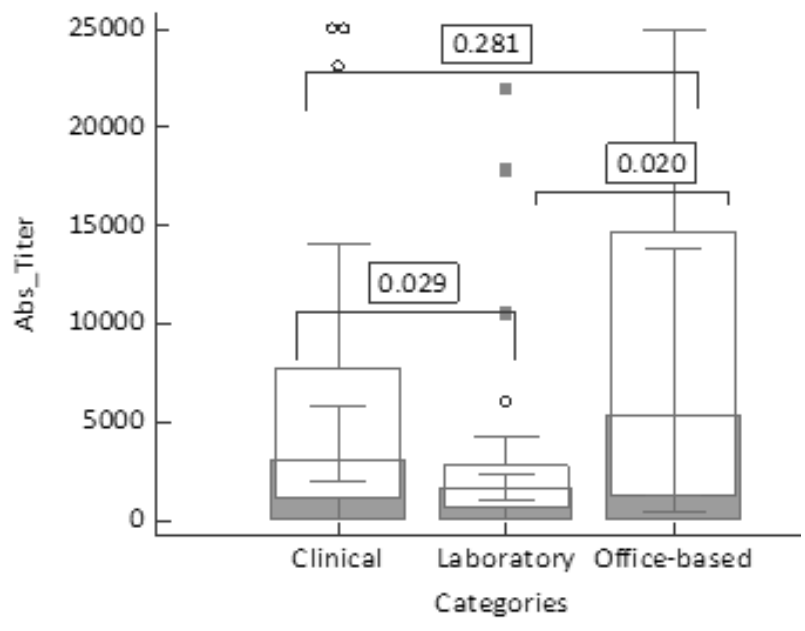

Figure 4. Anti-SARS-CoV-2 $\mathrm{S}$ antibody titers $(\mathrm{U} / \mathrm{mL})$ in relation to working location (laboratory, clinical settings, and office)

Notes: Differences between groups were analyzed using the Kruskal-Wallis test for nonparametric data. The white box represents IQR, the grey box represents the lowest quartile, the horizontal line inside the box represents the median, the whiskers inside the box represent 95\% CI for the median. Whiskers represent the extend from the IQR to the maximum values that are not considered as outliers, square dots represent outliers.

The symptomatology during infection, and the side-effects induced by the vaccine (self-reported) together with the antibody levels in relation to symptoms in the post-COVID-19 patient and post-vaccine reactions are detailed in Table 2 .

Table 2. The anti-SARS-CoV-2 S antibody levels $(\mathrm{U} / \mathrm{mL})$ in studied groups with and without disease symptoms or postvaccine reactions

\begin{tabular}{|c|c|c|c|}
\hline Past infection group $(n=43)$ & Absent $(n=10)$ & Present $(n=33)$ & $p$ \\
\hline \multicolumn{4}{|c|}{ Self-reported disease symptoms } \\
\hline At least one symptom & $10(23.3 \%)$ & $33(76.7 \%)$ & \\
\hline Fatigue & - & $17(51.5 \%)$ & \\
\hline GI symptoms & - & $2(6.1 \%)$ & \\
\hline Muscle pain & - & $16(48.5 \%)$ & \\
\hline Anosmia & - & $17(51.5 \%)$ & \\
\hline Loss of taste & - & $15(45.4 \%)$ & \\
\hline Age (past infection group) & $49(36-57)$ & $43(22-58)$ & $p=0.03$ \\
\hline \multicolumn{4}{|c|}{ Antibody titers in relation with disease symptomatology } \\
\hline Anti-SARS-CoV-2 S & $10972.5(10060.0-25000.0)$ & $5966.0(3801.25-10278.25)$ & 0.013 \\
\hline \multicolumn{4}{|c|}{ Self-reported adverse post-vaccine reaction } \\
\hline Overall (n=89) & Absent $(n=67)$ & Present $(n=22)$ & $p$ \\
\hline At least one adverse reaction & & $22(24.7 \%)$ & \\
\hline Fatigue & & $10(12.2)$ & \\
\hline
\end{tabular}




\begin{tabular}{|c|c|c|c|}
\hline Local pain & - & $15(16.8 \%)$ & \\
\hline Chills and low-grade fever & - & $9(10.1 \%)$ & \\
\hline Headache & - & $5(5.6 \%)$ & \\
\hline Joint pain & - & $4(4.5 \%)$ & \\
\hline Muscle pain & - & $5(5.6 \%)$ & \\
\hline Anti-SARS-CoV-2 S & $2435.0(922.25-5902.750)$ & $3316.0(1381.0-10264.0)$ & $p=0.291$ \\
\hline
\end{tabular}

Notes: Self-reported symptoms expressed as number and percentage; antibody titers expressed as median (IQR) after MannWhitney analysis; GI=gastro-intestinal. Self-reported post-vaccine reactions were expressed as number and percentage.

We further analyzed antibody titers in relation to blood group, although no differences in plasma levels of anti-SARS-CoV-2 antibodies were found ( $p=0.356$ ) (data not shown), which is a similar result to another report [17]. Additionally, there was no correlation between frequency or intensity of post-vaccine symptoms with plasma antibody levels.

\section{Discussion}

In the present study, we investigated plasma levels of anti-SARS-CoV-2 antibodies among both medical and non-medical hospital staff, working in different specialties in a tertiary hospital. The antibody titer refers to the binding capacity of neutralizing antibodies, not to neutralization potency. However, according to the kit manufacturer, there is high concordance between binding and neutralizing capacity for the test used in our study [15]. A plasma sample with an antibody titer $\geq 15 \mathrm{U} / \mathrm{mL}$ has $100 \%$ probability of conferring in vitro protection against SARS-CoV-2 infection. This is an important factor for HWs, as medical staff are on the front line during the pandemic, in close contact with patients, so it is of great importance to evaluate the degree of immunization to limit the virus transmission. At the very least, immunization can prevent or limit the development of symptomatic disease, especially in relation to the B.1.617.2 (delta) variant due to a potent vaccine-induced immunity to this variant [18]. The plasma levels of SARS-CoV-2 antibodies were quantified in both previously infected and noninfected persons with a full dose of BNT162b2 mRNA vaccine (Pfizer-BioNTech). All participants developed a significant response to the vaccine, although there were some differences in antibody titers between the groups with and without past infection. Overall, the antibodies titers were significantly higher in previously infected and vaccinated subjects, compared to the vaccine-only group. Furthermore, there was no significant difference in post-vaccine responses between males and females, both for the entire cohort, or within the two subgroups. Both groups (vaccine-only and infected + vaccine) displayed a higher median antibody response for women compared to men, although the results did not reach the statistical significance. In relation to age, there was no difference in antibody titer between the two age groups, and similarly the antibody titers were higher in those participants that had been vaccinated following infection for both age groups. The enhanced immune response is attributed to pre-existing immune memory B cells due to previous viral exposure. This is evidenced by the 5 -fold higher humoral immune response in previously infected HWs and office-based personnel. A very recent paper published by Meschi et al. regarding the difference in antibody binding and neutralizing capacity in naïve versus previously infected HWs also reports a higher titer of anti-RBD antibodies, when measured after the second dose of vaccine in those subjects with past SARS-CoV-2 infection [19].

Interestingly, we found the highest titer in the office-based staff compared to doctors and nurses. However, the overall difference between groups was not statistically significant. Similarly, office-based subjects had the highest antibody titers $(p=0.023)$ in comparison with laboratory or clinical working areas, but this aspect was not maintained during subgroup analysis. In a study by Ogutlu et al. across HWs in the pre-vaccination period, only the nurses displayed significantly higher antibody titers in relation to viral exposure (not in relation to the vaccine) [20]. Similarly, in our study nurses that had been previously infected had significantly higher antibodies titers compared to doctors $(p=0.04)$, potentially explained by higher exposure to the virus and prolonged time spent around the patients. Despite the fact that using personal protective equipment (PPE) during medical procedures insures a high level of protection, the fact that nurses spent more time around the patients compared to doctors may represent a reasonable explanation for the discrepancy. With regards to PPE, it is most likely the same around the hospital regardless of the specific department. Furthermore, the time spent near SARS-CoV-2 infected patients in order to perform medical procedures and to ensure the daily care procedures is likely to be a determining factor for the amplitude of the immune response.

Like other reports, the COVID-19 symptoms and the adverse post-vaccine effects were not found to be strongly related to antibodies titers [21,22]. However, within the past infection group, plasma levels of antibodies 
were 2-fold higher in subjects that did not display symptoms, still, the number of subjects was relatively low. Additionally, this may result from self-reporting on the clinical forms and the degree of appreciation of the symptomatology. Furthermore, none of the subjects were hospitalized during their disease course. On the other hand, it is known that there was great variability in immune response and in the type of symptomatology during SARS-CoV-2 infection.

The study has some limitations, including small participant numbers and the preponderance of women, which may impact the results. The study took place in two hospital locations involved in the management of COVID-19 patients, although only one of them was designated as a COVID-19 hospital while the other was a supporting hospital. Interestingly, HWs from infectious disease clinics who were more exposed to the virus exhibited lower antibodies plasma levels compared to other medical staff included in the study. The reason for this could not be fully explained by the research team, especially as complete blood counts or other immune response tests were not evaluated, this being a limitation of the study. As expected, a high degree of anxiety, stress, and burnout was reported during the COVID-19 pandemic [23], and Sacadura-Leite et al. reported a reduction in humoral immune response post-vaccine in healthcare personnel, explained mostly by the chronic stress and burnout. The paper reports a significant relationship between a reduction in hemagglutination-inhibition (HAI) antibodies six months after flu vaccine and chronic stress in HWs [24]. There is a close relationship between stress and the neuroendocrine system throughout the hypothalamic-pituitary-adrenal (HPA) axis, one of the major stresssignaling pathways [25]. Stress or negative emotions seem to imbalance the B and T cell response [26] and one might speculate this is a reasonable explanation for the lower antibody levels among HWs from infectious disease departments.

Additionally, not all departments were represented in this analysis, many departments that are important in the COVID-19 pandemic, with high-risk exposure, like Intensive Care Units (ICU) or Emergency Departments were not represented in this study. Moreover, only a binding assay was performed and not a neutralization test, however according to the reagent manufacturer, there is a high correlation between the binding assay currently used in routine practice and the neutralization capacity of antibodies. This implies special equipment and conditions required for the IVD tests for neutralization capacity of anti-SARS-CoV-2 antibodies that may not be user-friendly for clinical laboratories.

Further studies are necessary for the permanent monitoring of the antibody levels in all categories of medical staff considered vulnerable groups, both for monitoring the levels of the antibody and for the duration of the immunity. As the new variants emerged, some studies revealed the effectiveness of vaccination against it, at least regarding the severity of the symptoms [27]. However, boosting immunity with serial doses of vaccine, even in cases of a past infection is important to maintain a sustained response of B cells in the germinal centers, allowing a robust and long-lasting humoral immunity to form [28].

\section{Conclusions}

This study revealed a sustained specific immune response after mRNA vaccine among the HWs, with enhanced response in the case of the previously infected subjects. However, as the protective threshold of these antibodies is questionable/unknown at this time, the third dose is administered in many countries for higher protection. Nevertheless, permanent monitoring of antibody levels in terms of amplitude and duration of the humoral response would be desirable in place of the empirical administration of the third dose, at least until results of third-dose clinical trials are made available. The HWs must bear in mind that their protection by any means is of paramount importance for the viability of the entire healthcare system in order to sustain its activity during pandemics.

\section{Disclosures and acknowledgments}

The authors declare no conflicts of interest with respect to the research, authorship, and/or publication of this article. This work was funded by an internal research grant no. 10126/1/17.12.2020 of "George Emil Palade" University of Medicine, Pharmacy, Science and Technology of Târgu Mureș, Romania. The authors thank Enikô Bakos and Maria Miheșan for their valuable contribution to the laboratory sample handling. 


\section{References:}

1. Post N, Eddy D, Huntley C, van Schalkwyk MCI, Shrotri M, Leeman D, et al. Antibody response to SARS-CoV-2 infection in humans: a systematic review. PLoS One. 2020; 15(12): e0244126. https://doi.org/10.1371/ journal.pone.0244126

2. www.ecdc.europa.eu [Internet]. Stockholm: European Centre for Disease Prevention and Control; 2021 Sep 8. Immune responses and immunity to SARS-CoV-2 [cited 2021 Nov 21]. Available from: https://www.ecdc. europa.eu/en/covid-19/latest-evidence/immune-responses

3. Goel RR, Apostolidis SA, Painter MM, Mathew D, Pattekar A, Kuthuru O, et al. Distinct antibody and memory $B$ cell responses in SARS-CoV-2 naïve and recovered individuals following mRNA vaccination. Sci Immunol. 2021; 6(58): 1-19. https://doi.org/10.1126/sciimmunol.abi6950

4. Smithgall MC, Dowlatshahi M, Spitalnik SL, Hod EA, Rai AJ. Types of assays for SARS-CoV-2 testing: a review. Lab Med. 2021; 51(5): E59-65. https://doi.org/10.1093/labmed/lmaa039

5. Liu G, Rusling JF. COVID-19 antibody tests and their limitations. ACS Sensors. 2021; 6(3): 593-612. https://doi.org/10.1021/acssensors.0c02621

6. Hanssen DAT, Slaats M, Mulder M, Savelkoul PHM, van Loo IHM. Evaluation of 18 commercial serological assays for the detection of antibodies against SARS-CoV-2 in paired serum samples. Eur J Clin Microbiol Infect Dis. 2021; 40(8): 1695-1703. https://doi.org/10.1007/s10096-021-04220-7

7. Kristiansen PA, Page M, Bernasconi V, Mattiuzzo G, Dull P, Makar K, et al. WHO International Standard for anti-SARS-CoV-2 immunoglobulin. Lancet (London, England). 2021; 397(10282): 1347-1348. https://doi.org/10.1016/S0140-6736(21)00527-4

8. Salazar E, Kuchipudi SV, Christensen PA, Eagar TN, Yi X, Zhao P, et al. Relationship between anti-spike protein antibody titers and SARS-CoV-2 in vitro virus neutralization in convalescent plasma. bioRxiv. 2020. https://doi.org/10.1101/2020.06.08.138990

9. Altawalah H. Antibody responses to natural SARS-CoV-2 infection or after COVID-19 vaccination. Vaccines. 2021; 9(8): 910. https://doi.org/10.3390/vaccines9080910

10. Yu S, Chen K, Fang L, Mao H, Lou X, Li C, et al. Comparison and analysis of neutralizing antibody levels in serum after inoculating with SARS-CoV-2, MERS-CoV, or SARS-CoV vaccines in humans. Vaccines. 2021; 9(6): 1-17. https://doi.org/10.3390/vaccines9060588

11. Benenson S, Oster Y, Cohen MJ, Nir-Paz R. BNT162b2 mRNA Covid-19 vaccine effectiveness among health care workers. N Engl J Med. 2021; 384(18): 1775-1777. https://doi.org/10.1056/NEJMc2101951

12. Keehner J, Horton LE, Pfeffer MA, Longhurst CA, Schooley RT, Currier JS, et al. SARS-CoV-2 infection after vaccination in health care workers in California. N Engl J Med. 2021; 384(18): 1774-1775. https://doi.org/10.1056/NEJMc2101927

13. www.cdc.gov [Internet]. Atlanta: Centers for Disease Control and Prevention. Background rationale and evidence for public health recommendations for fully vaccinated people. CDC COVID-19 Science Briefs. 2020 [cited 2021 Aug 20]. Available from: https://www.cdc.gov/coronavirus/2019-ncov/science/science-brief

14. Assis R, Jain A, Nakajima R, Jasinskas A, Kahn S, Palma A, et al. Distinct SARS-CoV-2 antibody responses elicited by natural infection and mRNA vaccination. bioRxiv. 2021; 2021.04.15.440089. https://doi.org/10.1101/2021.04.15.440089

15. www.roche.com [Internet]. Basel: F. Hoffmann-La Roche Ltd.InsertElecsys Anti-SARS-CoV-2 S.09289275500. V2.en [cited 2021 Nov 18]. Available from: https://pim-eservices.roche.com/eLD/api/downloads/

16. www.hse.ie [Internet]. Dublin: HSE National Immunisation Office. Immunisation [cited 2021 Nov 18]. Available from: https://www.hse.ie/eng/health/immunisation/

17. Nasiri M, Khodadadi J, Hajrezaei Z, Bizhani N. The probable association between blood groups and prognosis of Covid-19. Iran J Public Health. 2021; 50(4): 825-830. https://doi.org/10.18502/ijph.v50i4.6009

18. Abbasi J. Study suggests lasting immunity after COVID-19, with a big boost from vaccination. JAMA. 2021; 326: 376-377. https://doi.org/10.1001/jama.2021.11717

19. Meschi S, Matusali G, Colavita F, Lapa D, Bordi L, Puro V, et al. Predicting the protective humoral response to a SARS-CoV-2 mRNA vaccine. Clin Chem Lab Med. 2021; 59(12): 2010-2018. https://doi.org/10.1515/cclm2021-0700

20. Ogutlu A, Karabay O, Erkorkmaz U, Guclu E, Sen S, Aydin A, et al. Novel coronavirus seropositivity and related factors among healthcare workers at a university hospital during the prevaccination period: a cross-sectional study. Ann Clin Microbiol Antimicrob. 2021; 20(1): 31. https://doi.org/10.1186/s12941021-00436-9 
21. Herzberg J, Vollmer T, Fischer B, Becher H, Becker AK, Honarpisheh H, et al. SARS-CoV-2-antibody response in health care workers after vaccination or natural infection in a longitudinal observational study. medRxiv. 2021; 2021.06.09.21258648. https://doi.org/10.1101/2021.06.09.21258648

22. Müller L, Andrée M, Moskorz W, Drexler I, Walotka L, Grothmann R, et al. Age-dependent immune response to the Biontech/Pfizer BNT162b2 coronavirus disease 2019 vaccination. Clin Infect Dis. 2021; ciab381. https://doi.org/10.1093/cid/ciab381

23. Teo II, Chay J, Bun Cheung Y, Sung SC, Tewani KG, Fang Yeo L, et al. Healthcare worker stress, anxiety and burnout during the COVID-19 pandemic in Singapore: a 6-month multi-centre prospective study. PLoS One. 2021; 16(10): e0258866. https://doi.org/10.1371/journal.pone.0258866

24. Sacadura-Leite E, Sousa-Uva A, Rebelo-De-Andrade H, Ferreira S, Rocha R. Association between chronic stress and immune response to influenza vaccine in healthcare workers. Rev Port Saude Publica. 2014; 32(1): 18-26. https://doi.org/10.1016/j.rpsp.2013.09.002

25. Glaser R, Kiecolt-Glaser JK. Stress-induced immune dysfunction: implications for health. Nat Rev Immunol. 2005; 5(3): 243-251. https://doi.org/10.1038/nri1571

26. Seiler A, Fagundes CP, Christian LM. The impact of everyday stressors on the immune system and health. In: Choukèr A., editor. Stress challenges and immunity in space. Cham: Springer; 2020. https://doi.org/10.1007/978-3-030-16996-1_6.

27. Bernal JL, Andrews N, Gower C, Gallagher E, Simmons R, Thelwall S, et al. Effectiveness of Covid-19 vaccines against the B.1.617.2 (Delta) variant. N Engl J Med. 2021; 385: 585-594. https://doi.org/10.1056/ NEJMoa2108891

28. Turner JS, O'Halloran JA, Kalaidina E, Kim W, Schmitz AJ, Zhou JQ, et al. SARS-CoV-2 mRNA vaccines induce persistent human germinal centre responses. Nature. 2021; 596(7870): 109-113. https://doi.org/10.1038/ s41586-021-03738-2 